\title{
Food Analysis Labwork Guide as A Learning Media
}

\author{
Sulistiyawati*, Adi Cahya \\ Department Biology Education, Faculty of Science \& Technology, Universitas Islam Negeri Sunan Kalijaga \\ J1. Marsda Adisucipto Yogyakarta 55281, Indonesia \\ Email: tiyawati83@gmail.com
}

\begin{abstract}
Sulistiyawati, Cahya A. 2017. Food Analysis Labwork Guide as A Learning Media. Proc Internat Conf Sci Engin 1: $235-238$. This study aimed to produce practical guide labwork using a project-based learning models to know the quality of products and to produce practical guide that can be used as a learning media. The study consisted of a preliminary study in the form of carbohydrat tests such as: iodine test, seliwanoff's test and moore test. Lipid solubility test within alcohol, ether and chloroform. Protein tests: biuret test, test and xanthoprotein ninhydrin test. Vitamin $\mathrm{C}$ tests: benedict test and iodine test. The results of the research were developed into a practical guide with coreldraw x6 software applications and Microsoft Word 2010 through the stages of data entry into the software developer, the preparation of layout and provision of the activity in laboratory. The final result of the product was a user-based food testing laboratory project. The product guide assess by a subject expert, a media expert, a biology teacher, 5 peer reviewers, while experts responded that module classified into "very good" with a percentage of $85.80 \%$. The assessment from 20 students of class XI and XII High School get a percentage rating of $78.60 \%$ with good quality.
\end{abstract}

Keywords: Practical Handbook, Food Test, Project Based Learning, Learning Media

\section{INTRODUCTION}

Biology as science, provides hands-on experience and opportunity for student to think logically, critically, independently, creatively and innovatively. The handson experience can be given by conducting scientific work in laboratory (Sujarwanto, 2012). According to Agustina (2015), labwork can teach you the skills to investigate and to solve the problem and also to find the information. According to Murti (2014) practical activities make students more confident to explore a new thing that already received from the teacher. In addition, the laboratory activities can increase student's experience, develop a scientific attitude and make learning more meaningful. This idea was supported by Winarti (2014), which states that the lab-based learning is a knowledge from real experience of collaborative activities, reflection, and interpretation.

One of the concepts in biology teaching materials in secondary high school is food anaysis. As a material, food test is compex because it requires many equipments and materials. Practical guide is the user manual that can make students understand the concepts included in the test food. In addition, the guide can facilitate the students to be more active, creative and innovative. Therefore, practical guide will improve the independence, liveliness and creativity of students. One model that can be used on manual lab work is projectbased learning.

Project based learning is an instructional model that involves the centralization of significant questions and problems, problem solving, decision-making, the process of finding the source, giving the opportunity to the members to work collaboratively and close with the presentation of the real product. This project-based learning model not only examines the relationship between theory and practice, but also motivate students to reflect on what they learned in the learning on a real project. According Susanti (2013), project-based learning can increase the confidence of students, motivate to learn, improve creativity and increase selfesteem as well as build the knowledge, skills, and complexity, enabling students to think critically in depth and analyze topics that have meaning for students.

Food test labwork practical guide with project based learning are developed to make the students to be more active and creative in the lab. Students are expected to practice a labwork as stated in the guide practicum then uses the principle that has been obtained from the practical activities to other lab activities. In addition, the use of the model project based learning can foster curiosity of students so that students are motivated to learn more than just learning. It is powered by Maradona (2013), stated that the excess practicum namely: (1) students are trained to use the scientific method in dealing with all issues, (2) not easy to believe prior to prove it, (3) more active in thinking and doing, and (4) finding practical experience and skills, (5) inculcate scientific attitude. Margunayasa (2014), reinforces Maradona report to explain the practical purpose: (1) develop basic skills, such as the use of tools, measuring and observing, (2) improve the understanding of the subject matter, (3) develop problem-solving skills.

\section{MATERIALS AND METHODS}

This study included research and development research and used to produce a specific product and test the effectiveness of the product. Products developed in this study is a guide food testing lab project based learning as a learning media. 
The research was conducted with several stages, namely: (1) test performed in the laboratory of food UIN Sunan Kalijaga to test the carbohydrate: iodine test, seliwanoff's test and moore test. lidip test with oil solubility test in alcohol, ether and chloroform. Test test proteins include biuret, ninhydrin and xanthoprotein. Vitamin $\mathrm{C}$ with test test benedict and iodine, (2) product development lab user guide of the results obtained, and (3) test the product in SMA N 1 Sewon.

\section{RESULTS AND DISCUSSION}

This development is divided into three main stages, lab test of food, design manual lab work using software developer Corel Draw x6, and Microsoft Word 2010, and testing products to a biology teacher and SMA Negeri 1 Sewon student that were previously validated by experts and peer reviewers. Food test material is material that is less able to be taken up by the students because of the complexity of the matter so that the test has not been executed food. Development biology lab manual is done based on the principle of research and development. practicum developed user guide is biology lab manual class XI SMA on digestive system materials and models used is project-based learning.

Guide book based practicum project based learning that has been developed further validated by an expert material, one media expert, five peer reviewers and one teacher of biology. Further refinement suggestion guide based food testing lab project based learning from experts, peer reviewers and teachers improved in order to obtain practical guide based food testing project based learning valid. The results of expert assessment of the test lab guide project based learning-based foods are shown in Table 1. Assessment of the quality of products made by experts, are subject matter experts and media experts are presented in Table 1.

Table 1. Results of product quality assessment by experts.

\begin{tabular}{lllll}
\hline Aspect & The Highest Score Ideal & Score Assessment Results & Ideal Percentage (\%) & Quality \\
\hline Matter & 90 & 73 & 81.11 & VG \\
Language & 20 & 16 & 80 & VG \\
Activity program & 15 & 10 & 66.67 & G \\
Presentation & 125 & 109 & 87.2 & VG \\
Total & 250 & 208 & 83.20 & VG \\
\hline
\end{tabular}

Description: VG (Very Good), G (Good).

The quality of guide biology lab test material according to subject matter experts and food experts are very good with a percentage of $83.20 \%$. The results of product assessment by five peer reviewers are presented in Table 2.

Table 2. Results of product quality assessment by peer.

\begin{tabular}{lllll}
\hline Aspect & The Highest Score Ideal & Score Assessment Results & Ideals Percentage $(\%)$ & Quality \\
\hline Matter & 75 & 68.2 & 90.93 & VG \\
Language & 20 & 17.4 & 87 & VG \\
Activity program & 15 & 13.2 & 88 & VG \\
Presentation & 115 & 104.8 & 91.13 & VG \\
Total & 225 & 203.6 & 90.48 & VG \\
\hline Description: VG(Very Good) & & &
\end{tabular}

The quality guide biology lab test material by peer reviewer food was very good with a percentage of $90.48 \%$ ideals. The results of product assessment conducted by teachers of biology are presented in Table 3.

Table 3. Results of the quality of products by the teacher penialaian.

\begin{tabular}{lllll}
\hline Aspect & The Highest Score Ideal & Score Assessment Results & Ideals Percentage (\%) & Quality \\
\hline Matter & 75 & 66 & 88 & VG \\
Language & 20 & 13 & 65 & \\
Activity program & 15 & 14 & 93.33 & VG \\
Presentation & 115 & 96 & 83.47 & VG \\
Total & 225 & 189 & 84 & VG \\
\hline
\end{tabular}

Description: VG (Very Good). 
The quality guide biology lab test material according to the food was very good biology teacher with a percentage of $84 \%$ ideals. Recapitulation assessment of experts, peer reviewers and teachers as a whole are presented in Table 4.

Table 4. Results of product quality assessment by experts, peer and teacher.

\begin{tabular}{lllll}
\hline Aspect & The Highest Score Ideal & Score Assessment Results & Ideals Percentage (\%) & Quality \\
\hline Matter & 240 & 207.2 & 86.33 & VG \\
Language & 60 & 46.4 & 77.33 & G \\
Activity program & 45 & 37.2 & 82.67 & VG \\
Presentation & 355 & 309.8 & 87.26 & VG \\
Total & 700 & 600.6 & 85.8 & VG \\
\hline Description: VG (Very Good), G (Good). & & &
\end{tabular}

The quality guide biology lab test material overall very good food with a percentage of $85.8 \%$ ideals.

User guide based food testing lab project based learning is the result of further development of the students tested. The purpose of the product is tested to determine the extent of the effectiveness of manual laboratory-based food testing project based learning in terms of the development of cognitive, psychomotor and affective aspects. Product test performed in SMA N 1 Sewon by doing practical work. Based on the test results of the product, the score from the students's responses in Table 5.

Table 5. Student responses to the product user guide practicum.

\begin{tabular}{lllll}
\hline Aspect & The Highest Score Ideal & Score Assessment Results & Ideals Percentage (\%) & Quality \\
\hline Student response & 75 & 58.95 & 78.6 & G \\
\hline Description: VG (Very Good), G (Good). & & &
\end{tabular}

The quality guide biology lab test material according to student have good quality with a percentage of $78.6 \%$.

Based on the evaluation then it can be concluded that the practical user guide with project based learning models included in excellent quality. Food test labwork practical guide with project based learning which was developed has met the aspects contained in the main component of project based learning adapted from Warsono and Hariyanto (2012) and Hosnan (2014), namely the emphasis on planning component or design project, project monitoring, write down the results of the project (report preparation and presentation of the project), as well as assessment and evaluation. The practical guide developed in a very good quality with a percentage of $85.8 \%$ ideals.

The results of the analysis of students' response to the food test labwork practical guide with project based learning in good quality with a percentage of $78.6 \%$ ideals. According to students, the lab developed guide can add insight that can motivate students to learn biology. Moreover, the theme of "test-based food project based learning" is selected very close to the daily life of students, and help particulary to develop the knowledge acquired. This is consistent with the theory put forward by Larmer \& Mergendoller (2010) that the project-based learning is able to provide the opportunity for students to develop 21st century skills such as collaboration, communication, critical thinking and the use of technology that will be meaningful-use in the world of work and real life. In addition, the user practical results of development in accordance with one of the benefits the user guide practicum according Arsyad (2011) which can increase and direct the student's attention so that it can increase learning motivation, direct interaction between students in the environment and the possibility of students to learn independently according to ability and interests.

Based on the discussion that have been been described, guide biology lab-based food testing project based learning has been qualified as teaching biology teaching materials. Excess product that lies in the design food test labwork practical, the project contained in the book is able to direct students to solve a problem through the creation of the project. This is in accordance with the opinion of Mahanal, et al (2014) which states that the project-based learning is the learning that is grounded in the principles of constructivism and contextual, for example learning that is likely to provide an immersive experience by providing opportunities for students to use the activity of inquiry, real and associated with life students. Opinion was supported by Kamdi (2007) which states that the benefits of projectbased learning that can improve the ability to think, because in the project activities, students not only receive information, but also develop problems, seek answers and collaborate to solve the problems that are relevant to the real truth, Excess development of manual lab work by Handoko (2016) are: (1) acquire new knowledge and skills in learning, (2) improve students' skills in problem solving, (3) makes the students more active in solving complex problems with the results of a real product in the form of goods or 
services, and (4) develop and enhance students' skills in managing resources / materials / tools to complete the task.

\section{CONCLUSIONS}

Based on the results obtained, we conclude: (1) manual laboratory test based food project based learning in a very good quality, (2) test product user guide lab testing of food based project based learning indicates a good quality product that deserves to be used as instructional media.

\section{REFERENCES}

Agustina, P. 2015. Prospective Biology Teacher Student Perceptions of High School Biology Lab Development: Learning Development Studies in Biology Education Student FKIP Muhammadiyah University of Surakarta, Bioedukatika Journal, 3 (2): 26-29

Arsyad, Azhar. 2011. Learning Media. Jakarta: King Grafindo Persada

Handoko, A., Sajidan., And Maridi. 2016 Module Development Biology Discovery-Based Learning (Part of Inquiry Spectrum Learning-Wenning) on Biotechnology Material Class XII Science in SMA N 1 Magelang in Academic Year 2014/2015. Inquiry Journal Vol 5 No. 3 pages 144-154

Hosnan. 2014. Scientific and Contextual Approach in the 21st Century Learning Bogor: Ghalia Indonesia
Kamdi, W. 2007. Based Learning Project (Project Based Learning). Training Material for Teachers in YPC Videos

Larmer \& Mergendoller. 2010. Seven Essentials for Project Based Learning. Buck Institute for Educational Leadership, 68 (1) 34-37

Mahanal, S., Ericka, D., AD Corebima., And Siti, Z. 2010. Effect of Learning Project Based Learning in the Content Ecosystem to Attitude and Learning Outcomes SMA N 2 Malang. Department of Biology, State University Negeri Malang

Maradona. 2013. Analysis of Science Process Skills Student Class XI IPA SMA Islam Samarinda Subject Hydrolysis Through Experimental Methods, Proceedings of the National Seminar 2013

Margunayasa, IG and Putunanci R. 2014. Influence Practice Guidelines IPA Charged Conceptual Change Concepts Against Increasing Understanding of Science in Student PGSD, Indonesia Education Journal, 3 (1)

Murti, S., Muhibbuddin, and Cut N. 2014. Implementation Based Learning Lab for Cognitive and Psychomotor Upgrades in Class Plant Anatomy, Biology Education Journal 12, 6 (1): 1 8

Sujarwanta, A. 2012. Conditioned ipa learning approach scientific. Nuance journal kependidikan, 16 (1), 75-83.

Susanti. 2013. Effect of Project Based Learning on Creative Thinking Ability and Attitude of Students in the Creative Scientific Nutrition, Journal of Teachers of Mathematics, 18 (1): $36-42$

Warsono and Hariyanto. 2013. Active Learning: Theory and Assessment. Bandung: PT Young Rosdakarya

Winarti, T and Sri N. 2014. Project Oriented Learning Lab to Enhance Science Process Skills and Understanding Concepts. Innovation Journal of Chemical Education, 8 (2): 1409-1420 